\title{
Performance Evaluation of Bullock Drawn Three-Row Inclined Plate Planter
}

\author{
Prerana Priyadarsini Jena ${ }^{1}$ and Suryakanta Khandai ${ }^{2 *}$ \\ ${ }^{1}$ Department of Farm Machinery and Power, CAET, OUAT, Bhubaneswar, \\ Odisha-751003, India \\ ${ }^{2}$ Department of Farm Machinery and Power Engineering, Sam Higginbottom University of \\ Agriculture, Technology and Sciences, Allahabad - 211007, (U.P.), India \\ *Corresponding author
}

\begin{tabular}{|l|}
\hline Ke y w o r d s \\
CIAE animal drawn \\
planter, Draft, Seed \\
placement, Field \\
capacity, Cost- \\
economics.
\end{tabular}

\section{Introduction}

Agricultural development is usually regarded as a major requirement for overall development of any country. Crop cultivation in India requires application of both animate (bullock, human power) and inanimate (tractors, tillers etc.) forms of energy at different stages. After tillage operation, sowing is done. Sowing is an art of placing seeds in the soil to have good germination in the field. Different types of sowing methods generally adopted are (i) Broadcasting (ii)
Dibbling (iii) Seed dropping behind the plough and Hill dropping (iv) Seed Drill and Planter. Broadcasting is the method of random scattering of seeds on the surface of seedbed. It can be done manually or mechanically. Soon after broadcasting, the seeds are covered by planking or some other devices. Usually higher seed rate is obtained in this system. Dibbling is the process of placing seeds in holes made in the seedbed and closing the seed with soil. In this method, 
seeds are placed in holes made at definite depth at fixed spacing. The equipment used for dibbling is called dibbler. Mostly vegetables are sown in this way. Seed dropping behind the plough is a very common method of sowing followed by the farmers in villages. This method is used for seeds like maize, gram, peas, wheat and barley. A woman/ man walk behind the plough and drop the seeds in the furrows made by plough. This method is a slow and laborious one. In hill dropping method, few seeds are dropped as a hill at a fixed place and not in a continuous stream. The spacing between hill to hill in a row is constant. A perfect sowing gives, correct amount of seed per unit area, correct depth of sowing, correct spacing between row-to-row and plant to plant and correct seed rate which can be achieved by use of seed drills or planters. Use of these implements not only reduces human drudgery and laborer cost but also ensures the timeliness of operation. Of course proper field preparation with finely pulverized soil is a pre requisite for better performance of the seed drill and planter. In seed drill seeds are dropped the in furrow lines of the drill in a continuous stream and covering them with soil. But the spacing between the seeds is not uniform. The number of rows may be one or more. Planter is sowing equipment used for sowing those seeds which are larger in size and cannot be handled by seed drills. Row to row and plant to plant spacing is maintained in a planter. Function of a planter is to open the furrow, meter the seed, deposit the seed in the furrow, covering the seed with soil.

To achieve the best performance from a seed drill or planter, the above factors are to be optimized by proper design and selection of the components required on the machine to suit the needs of the crops. The seed drill or planter can play an important role in manipulating the physical environment. The metering system selected for the seed should not damage the seed while in operation. The speed of metering device is a very important factor with regards to damage. Seed damage can be avoided by selecting the proper spring loading rate of the cut-off device and knockout device in case of plate type planters.

The bullocks and buffaloes are the main stay of farm power in India and they still command over $60 \%$ of the total cultivable land. About $90 \%$ of the tillage operation in India is still carried out by the draught animals. The marginal farmers who constitute $80 \%$ of the total farming community of the country with low purchasing capacity extensively depend on draught animal power for different agricultural operations.

At the same time shortage of agricultural laborers due to rapid urbanization is a constraint in crop production. In this context there is a huge scope for introduction of various matching bullock drawn implements like seed drills and planters. According to Adekanye et al., (2015) the field capacity of a multi-crop planter is $76.3 \%$ and seed rate varies from 0.18 to $0.25 \mathrm{~kg} / \mathrm{ha}$ for different crops. The present study on "performance evaluation of an animal-drawn three row inclined plate planter" was undertaken with the following objectives:

To study the performance of CIAE animal drawn three row inclined plate planter for sowing of maize.

To compare the cost-economics of the inclined plate planter and seed dropping behind the plough.

\section{Materials and Methods}

A CIAE developed animal drawn 3 row inclined plate planter was tested for sowing of maize with a pair of medium size bullock having a pair weight of $520 \mathrm{~kg}$. Field trials were conducted in the Central Farm of OUAT, Bhubaneswar situated at latitude 
$20.27^{0} \mathrm{~N}$ and longitude $85.84^{0} \mathrm{E}$ at an elevation of $45 \mathrm{~m}$ above the sea level.

\section{Features of inclined plate planter}

The inclined plate planter is a multi-crop planter developed for planting of bold and small seeds. It has three independent seed boxes with inclined plate edge drop type seed metering mechanism. The planter has shoe type furrow openers which ensure deeper seed placement in moist zone for sowing under dry land conditions. An optional fertilizer box with fluted roller type metering system can also be mounted on the main frame for application of granular fertilizers.

Power from ground wheel is transmitted to the counter drive shaft through a set of chain and sprockets. Another set of sprockets on the counter shaft transmits the power to main drive shaft. Main drive shaft drives the individual drive shafts of modular seed boxes through sets of chain and sprockets and these shafts in turn rotate the inclined seed metering plates through a set of bevel gears.

Drive ratio between ground drive wheel and seed plate can be changed, by selecting appropriate size of sprocket on wheel axle or on counter and main drive shafts.

\section{Calibration of planter}

The animal drawn 3 row inclined planter was calibrated to get the desired seed rate for the crop taken i.e., maize. Wide range of quantity of seeds dropped through the inclined plate was collected during the calibration of planter. For calibration of planter:

Nominal width of planter was determined i.e. number of furrows $\mathrm{x}$ spacing between the openers. Nominal width $=30 \times 3=90 \mathrm{~cm}=$ $0.9 \mathrm{~m}$
Diameter of ground wheel was found out i.e. total diameter +1 peg height $=42 \mathrm{~cm}=$ $0.42 \mathrm{~m}$.

The planter was jacked up. A mark on the ground wheel to count revolutions was made. Ten revolutions were taken. Distance covered in 1 revolution $=\pi \mathrm{D}=1.32 \mathrm{~m}^{2}$. For 10 revolutions, area covered $=1.32 \times 10=13.2 \mathrm{~m}^{2}$

Seed was put in seed box.

Seeds dropped from each furrow were collected, counted and weighed.

Seeds dropped in $\mathrm{kg} / \mathrm{ha}$ were calculated and recorded.

The process was repeated for different speeds (1.5 to $3 \mathrm{~km} / \mathrm{h}$ ) and for different hopper capacity to get the desired seed rate.

No. of seeds dropped per box in 10 revolutions $=60$

Required row to row distance $=45 \mathrm{~cm}$, Seed to seed distance $=30 \mathrm{~cm}$, No. of seeds per ha $=$ 45,454

As 1000 seeds weigh 250gram, 45454 seeds weigh $=11.3 \mathrm{~kg}$

As from calibration of the inclined plate planter, the seed rate was found nearly equal to the desired seed rate for maize i.e. 12 $\mathrm{kg} / \mathrm{ha}$; at full hopper capacity and speed of $1.5 \mathrm{~km} / \mathrm{h}$, the inclined plate planter can be used for sowing of maize appropriate spacing.

\section{Determination of soil moisture}

The soil sample was collected on the day of operation and kept in clean moisture cups, weighed and put with lid opened in a thermostatically controlled oven with interior of non-corroding material to maintain the 
temperature between $105^{\circ} \mathrm{C}$ to $110^{\circ} \mathrm{C}$. Weight of the samples were taken every 24 hours intervals till the weight became constant, so that complete drying is assured. After drying, the container is removed from the oven and allowed to cool in desiccators before weighing.

The water content was calculated from the following expression:

$\mathrm{W}=\left(\mathrm{M}_{2}-\mathrm{M}_{3}\right) /\left(\mathrm{M}_{3}-\mathrm{M}_{1}\right) * 100$

Where,

$\mathrm{M}_{1}=$ mass of the container with lid

$\mathrm{M}_{2}=$ mass of container with lid and wet soil

$\mathrm{M}_{3}=$ mass of container with lid and dry soil

\section{Measurement of physiological parameters of bullocks and ambient conditions}

The hourly ambient temperature and relative humidity were recorded by a room temperature recorder and a hygrometer, respectively during the experimental period. The instruments were kept hanging from a stand during the work at the experimental site.

Heart rate of the bullocks was measured by using a stethoscope, putting it on left side of the chest in between 4th to 6th rib for one minute. Respiration rate was measured by feeling the blows of expired air on the backside of the palm over nostril for one minute. Body temperature was recorded from rectal wall by help of a clinical thermometer. The degrees of distress symptoms like frothing, leg in-coordination, excitement, inhibition to progressive movement and tongue protrusion were recorded by visual observations.

Fatigue score of the bullocks was determined as per the fatigue scorecard (Table 2) developed by Upadhyay and Madan (1985).
In this scorecard, one point is scored for every rise of ten counts in heart rate, fifteen counts in respiration rate and $0.5^{0} \mathrm{C}$ in body temperature. Similarly, points are scored for different degrees of distress symptoms like frothing, leg in-coordination, excitement, inhibition to progressive movement and tongue protrusion as manifested by the bullocks during work.

The maximum point can be scored, for any response or symptom is 5 and the total score of all eight fatigue parameters in this scorecard is 40 . But the bullocks are said to be fatigue when total score reaches 20 i.e. $50 \%$ of the highest score.

\section{Field experiments}

The theoretical field obtain if implement was performing its function $100 \%$ of the time at the rated speed and always covering $100 \%$ of its rated width. Field capacity was calculated by following expression:

$\mathrm{TFC}=(\mathrm{W} \times \mathrm{S}) / 10$

Where,

TFC $=$ theoretical field capacity,

$\mathrm{W}=$ theoretical width of implement, $\mathrm{m}$ and $\mathrm{S}$ $=$ speed of operation.

Actual field capacity was determined by expression given as:

$\mathrm{AFC}=\mathrm{A} / \mathrm{T}$

Where,

$\mathrm{AFC}=$ Actual field capacity, $\mathrm{A}=$ actual area covered by implement, ha and $\mathrm{T}=$ effective time, h.

Field Efficiency is determined by the ratio of actual field capacity and theoretical field capacity. 
Draft was measured by using a dynamometer (Fig. 1). Power output in $\mathrm{kw} / \mathrm{h}$ was determined by expression given as:

$\mathrm{P}=$ Draft in $\mathrm{kg} \times$ Speed in $\mathrm{km} \times 0.0028 \mathrm{~kW} / \mathrm{h}$

Average seed to seed and row to row distance was measured.

Depth of placement of seed was measured using a steel ruler.

Area was measured using pegs and measuring tape. And time was noted using stop watch. These measurements were taken for calculating actual field capacity.

\section{Results and Discussion}

The field evaluation of the animal drawn 3row inclined plate planter was done at the Central farm of OUAT, Bhubaneswar, Odisha during summer season. The crop taken was maize of variety PDM 54. The soil of experimental site comes under sandy loam texture. The field was ploughed thrice for well pulverization of the soil which is a prerequisite for smooth operation of seed drill/ planter. The soil moisture content was $21.02 \%$ and the mean diameter of the clods was $0.38 \mathrm{~mm}$. The entire field was divided in to two equal portions for sowing of maize by inclined plate planter and behind the plough (Traditional practice) for comparison of different machine and crop parameters. The performance of the inclined plate planter and sowing behind the plough has been presented in Table 3.

\section{Inclined plate planter}

The draft requirement for the operation was varied from $372.4 \mathrm{~N}$ initially to $401.8 \mathrm{~N}$ at $2^{\text {nd }}$ hour of operation with an average power output of $0.158 \mathrm{~kW}$. The average speed of operation of the planter was found to be 1.46 $\mathrm{km} / \mathrm{h}$. The average seed to seed distance was $30 \mathrm{~cm}$ and average row to row distance is 45 $\mathrm{cm}$. The depth of seed placement was $6 \mathrm{~cm}$ and actual seed rate observed was $11.2 \mathrm{~kg} / \mathrm{ha}$. The mean draft requirement measured during experiment was $384.17 \mathrm{~N}$. The theoretical field capacity was $0.127 \mathrm{ha} / \mathrm{hr}$. The field efficiency calculated was $70.5 \%$. Average number of plants per hill was one. Cost of labour charges was Rs 500.00 per ha in sowing with three row inclined plate planter.

The physiological responses of the bullocks during the operation of the inclined plate planter have been presented in Table 4 . Ambient temperature ranged from $30^{\circ} \mathrm{C}$ to $32^{\circ} \mathrm{C}$ and relative humidity ranged from $56 \%$ to $70 \%$. The heart rate, respiration rate and body temperature increased up to 72 beats/min, 36 blows $/ \mathrm{min}$ and $38.7^{\circ} \mathrm{C}$ after two hour of operation. The fatigue score of the bullocks was observed to be 15 , well within safe limit of 20. Thus, a medium pair bullock could be able to operate the inclined plate planter comfortably.

\section{Behind the plough}

The average speed of operation behind the plough was $1.54 \mathrm{~km} / \mathrm{h}$. The average seed to seed distance was $27.5 \mathrm{~cm}$ and average row to row distance is $41 \mathrm{~cm}$. The average depth of seed placement was $8 \mathrm{~cm}$ and actual seed rate observed was $22.5 \mathrm{~kg} / \mathrm{ha}$. The mean draft measured during experiment was observed to be $351.83 \mathrm{~N}$. The theoretical field capacity was found to be $0.075 \mathrm{ha} / \mathrm{hr}$. The field efficiency calculated to be $59 \%$. Average number of plants per hill was 1.34. Cost of labour charges was Rs 2140.00 per ha in sowing behind the plough. The physiological responses of the bullocks during the sowing behind the plough have been presented in Table 5. Ambient temperature ranged from $31^{\circ} \mathrm{C}$ to $32.4^{0} \mathrm{C}$ and relative humidity ranged from $58 \%$ to $69 \%$. 
Table.1 Specifications of the CIAE inclined plate planter

\begin{tabular}{|l|l|l|}
\hline S. No. & \multicolumn{1}{|c|}{ Particulars } & \multicolumn{1}{c|}{ Specifications } \\
\hline 1 & Overall dimensions $(\mathrm{mm})$ & $1200 \times 1300 \times 900$ \\
\hline 2 & Number of rows & 3 (row spacing adjustable from 25 to $45 \mathrm{~cm})$ \\
\hline 3 & Seed metering & Inclined plate with cells, $120 \mathrm{~mm}$ diameter \\
\hline 4 & Fertilizer metering & Aluminum fluted rollers \\
\hline 5 & Furrow openers & Shoe type \\
\hline 6 & Power source & Medium size pair of bullock \\
\hline 7 & Power transmission & Through chain \& sprocket and bevel gear \\
\hline 8 & Ground wheel & Present \\
\hline 9 & Depth Adjustment wheel & Present $(2$ nos.) \\
\hline 0 & Clutch mechanism & Available \\
\hline 1 & Seed \& fertilizer channel & Plastic tube (1") \\
\hline 2 & Seed \& fertilizer dropping & Free flow by gravity \\
\hline
\end{tabular}

Table.2 Fatigue scorecard for bullocks

\begin{tabular}{|c|c|c|c|c|c|c|}
\hline \multirow{2}{*}{$\begin{array}{l}\text { Physiological } \\
\text { responses }\end{array}$} & \multicolumn{5}{|c|}{ Scores } & \multirow{2}{*}{$\begin{array}{c}\text { Maximum } \\
\text { score }\end{array}$} \\
\hline & 1 & 2 & 3 & 4 & 5 & \\
\hline $\begin{array}{l}\text { Heart rate } \\
\text { (beats/min) }\end{array}$ & $\mathrm{H}+10$ & $\mathrm{H}+20$ & $\mathrm{H}+30$ & $\mathrm{H}+40$ & $\mathrm{H}+50$ & 5 \\
\hline $\begin{array}{l}\text { Resp. rate } \\
\text { (blows/min) }\end{array}$ & $R+15$ & $\mathrm{R}+30$ & $R+45$ & $R+60$ & $\mathrm{R}+75$ & 5 \\
\hline Body temp $\left({ }^{0} \mathrm{C}\right)$ & $\mathrm{T}+0.5$ & $\mathrm{~T}+1.0$ & $\mathrm{~T}+1.5$ & $\mathrm{~T}+2.0$ & $\mathrm{~T}+2.5$ & 5 \\
\hline Frothing & First appearance & $\begin{array}{c}\text { Dribbling of } \\
\text { saliva }\end{array}$ & $\begin{array}{c}\text { Continuous } \\
\text { dribbling }\end{array}$ & $\begin{array}{c}\text { Appearance of } \\
\text { froth }\end{array}$ & $\begin{array}{l}\text { Full mouth } \\
\text { frothing }\end{array}$ & 5 \\
\hline Leg in-coordination & Strides uneven & $\begin{array}{c}\text { Occasional } \\
\text { dragging }\end{array}$ & $\begin{array}{l}\text { Frequent } \\
\text { dragging }\end{array}$ & $\begin{array}{c}\text { No co- } \\
\text { ordination }\end{array}$ & Unable to move & 5 \\
\hline Excitement & Composed & Disturbed & Nostrils dilated & Eye balls dilated & Furious ness & 5 \\
\hline $\begin{array}{l}\text { Progressive } \\
\text { movement }\end{array}$ & Brisk & Free & Slow & Very slow & Stop walking & 5 \\
\hline Tongue protrusion & Mouth closed & $\begin{array}{l}\text { Occasional } \\
\text { opening }\end{array}$ & $\begin{array}{c}\text { Frequent } \\
\text { appearance }\end{array}$ & $\begin{array}{l}\text { Continuous } \\
\text { protrusion }\end{array}$ & Tongue fully out & 5 \\
\hline
\end{tabular}

Table.3 Performance evaluation of inclined plate planter and sowing behind the plough

\begin{tabular}{|l|l|l|l|}
\hline Sl. No. & Particulars & Inclined plate planter & Behind the plough \\
\hline 1 & Crop & Maize & Maize \\
\hline 4 & Type of soil & Sandy loam & Sandy loam \\
\hline 5 & Soil moisture, $(\mathrm{db})$ & 21.02 & 21.02 \\
\hline 6 & Mean weight diameter of clods, $\mathrm{mm}$ & 0.38 & 0.38 \\
\hline 7 & Average speed, $\mathrm{km} / \mathrm{hr}$ & 1.46 & 1.54 \\
\hline 8 & Avg. seed to seed distance, $\mathrm{cm}$ & $30 \mathrm{~cm}$ & $27.5 \mathrm{~cm}$ \\
\hline 9 & Average row to row distance, $\mathrm{cm}$ & $45 \mathrm{~cm}$ & $41 \mathrm{~cm}$ \\
\hline 10 & Depth of seed placement, $\mathrm{cm}$ & 6 & 8 \\
\hline 11 & Actual seed rate observed, $\mathrm{kg} / \mathrm{ha}$ & 11.2 & 22.5 \\
\hline 13 & Draft, $\mathrm{kg}$ & $39.3 \mathrm{~kg}(7.5 \%$ of the body weight $)$ & $35.9 \mathrm{~kg}(6.9 \%$ of the body weight $)$ \\
\hline 14 & Theoretical field capacity, ha/hr & 0.127 & 0.075 \\
\hline 15 & Field efficiency, $(\%)$ & 70.5 & 59 \\
\hline 16 & Average number of plants /hill & 1 & 1.34 \\
\hline 17 & Labour cost $(\mathrm{Rs} /$ ha) & 500.00 & 2140.00 \\
\hline
\end{tabular}


Table.4 Physiological parameters of Bullocks during sowing with inclined plate planter

\begin{tabular}{|l|c|c|c|c|c|c|}
\hline \multirow{2}{*}{ Parameters } & \multicolumn{7}{|c|}{ Duration of work } \\
\cline { 2 - 7 } & Initial & $\mathbf{0 . 5}$ & $\mathbf{1 . 0}$ & $\mathbf{1 . 5}$ & $\mathbf{2}$ & Mean \\
\hline Amb. Temp., ${ }^{0} \mathrm{C}$ & 30 & 30.4 & 30.9 & 31.4 & 32 & 30.94 \\
\hline Rh, \% & 56 & 59 & 62 & 66 & 70 & 62.6 \\
\hline Draft, N & - & 372.4 & 377.3 & 385.2 & 401.8 & 384.17 \\
\hline Speed, km/h & - & 1.50 & 1.46 & 1.44 & 1.42 & 1.46 \\
\hline Pulse rate, bpm & 48 & 56 & 60 & 66 & 72 & - \\
\hline Respiration rate, bpm & 14 & 18 & 26 & 30 & 36 & - \\
\hline Body Temp, ${ }^{0} \mathrm{C}$ & 37.5 & 37.9 & 38.2 & 38.4 & 38.7 & - \\
\hline Fatigue score & - & 9 & 11 & 13 & 15 & - \\
\hline Power output, $\mathrm{kW} / \mathrm{h}$ & - & 0.154 & 0.156 & 0.159 & 0.166 & 0.158 \\
\hline
\end{tabular}

Table.5 Physiological parameters of bullocks during sowing behind the plough

\begin{tabular}{|l|c|c|c|c|c|c|}
\hline \multirow{2}{*}{ Parameters } & \multicolumn{7}{|c|}{ Duration of work } \\
\cline { 2 - 7 } & Initial & $\mathbf{0 . 5}$ & $\mathbf{1 . 0}$ & $\mathbf{1 . 5}$ & $\mathbf{2}$ & mean \\
\hline Amb. Temp., ${ }^{0} \mathrm{C}$ & 31 & 31.4 & 31.8 & 32.2 & 32.4 & 31.77 \\
\hline Rh, \% & 58 & 61 & 64 & 67 & 69 & 63.8 \\
\hline Draft, $\mathrm{N}$ & - & 343 & 347.8 & 354.7 & 360.6 & 351.53 \\
\hline Speed, km/h & - & 1.60 & 1.56 & 1.50 & 1.48 & 1.54 \\
\hline Pulse rate, bpm & 48 & 54 & 58 & 62 & 66 & - \\
\hline Respiration rate, bpm & 14 & 18 & 24 & 28 & 32 & - \\
\hline Body Temp, ${ }^{0} \mathrm{C}$ & 37.5 & 37.8 & 38.1 & 38.3 & 38.6 & - \\
\hline Fatigue score & - & 9 & 10 & 12 & 14 & - \\
\hline Power output, $\mathrm{kW} / \mathrm{h}$ & - & 0.151 & 0.153 & 0.156 & 0.158 & 0.155 \\
\hline
\end{tabular}

Table.6 Comparison of cost economics of sowing with animal drawn inclined plate planter and behind the plough

\begin{tabular}{|l|c|c|c|}
\hline \multicolumn{1}{|c|}{ Machine } & Fixed cost, Rs/h & Variable cost, Rs/h & Total cost, Rs/h \\
\hline Three row planter & 1.17 & 0.67 & 1.84 \\
\hline Bullock pair & 3.91 & 5.00 & 8.91 \\
\hline One pair bullock + one labourer & 3.91 & 16.00 & 19.91 \\
\hline Sowing with three row planter & - & - & $\mathbf{3 0 . 6 6}$ \\
\hline Sowing behind the plough & - & - & $\mathbf{5 0 . 0 0}$ \\
\hline
\end{tabular}




\section{Inclined plate planter and it seed metering mechanism}
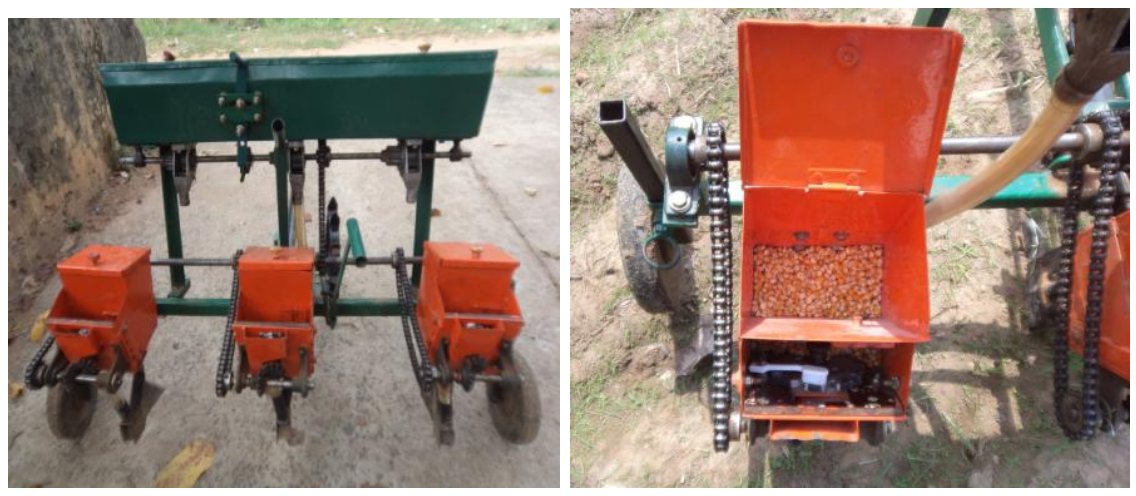

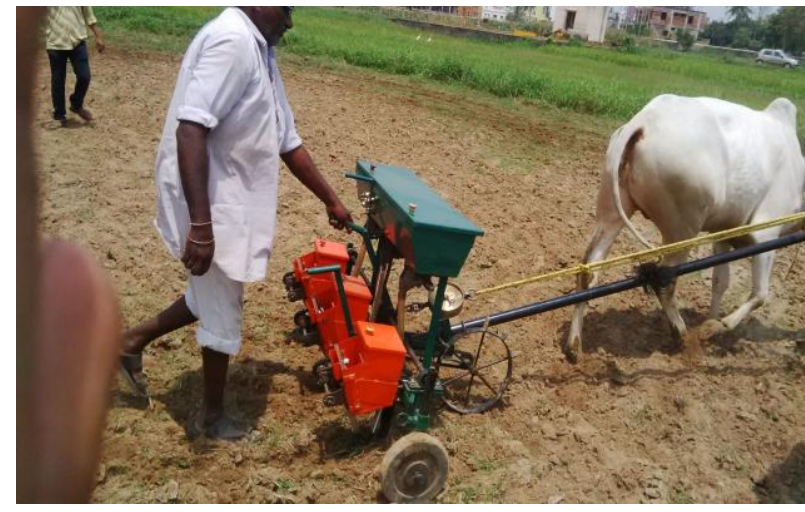

Fig.1 Draft measurement of planter by dynamometer

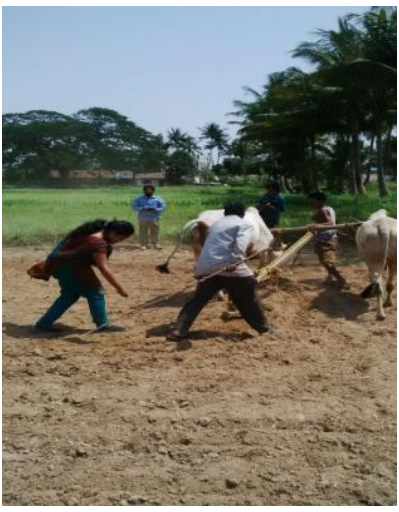

Fig.2 Sowing behind the plough
The heart rate, respiration rate and body temperature increased up to 66 beats/min, 32 blows/min and $38.6^{\circ} \mathrm{C}$ after two hour of operation. The fatigue score of the bullocks was observed to be 14 , well within safe limit of 20 .

Thus, a medium pair bullock could be able to operate the inclined plate planter comfortably. The cost economics of sowing of maize with animal drawn planter and behind the plough was compared. It was found that cost of sowing with three row inclined plate planter was Rs30.00/ $\mathrm{h}$ and sowing behind the plough was Rs50.00/ h (Fig. 2).

A CIAE developed animal drawn 3 row inclined plate planter was tested for sowing of maize with a pair of medium size bullock having a pair weight of $520 \mathrm{~kg}$. The planter has adjustable seed boxes along with shoe type furrow openers. Power from ground wheel is transmitted through sets of chain and sprockets and in turn rotates the inclined seed metering plates through a set of bevel gears. The entire field was divided in to two equal portions for sowing of maize by inclined plate planter and behind the plough (Traditional practice) for comparison of different machine and crop parameters.

The mean draft requirement measured during experiment was $384.17 \mathrm{~N}$ with an average power output of $0.158 \mathrm{~kW} / \mathrm{h}$. The average speed of operation of the planter was found to be $1.46 \mathrm{~km} / \mathrm{h}$. The average seed to seed distance was $30 \mathrm{~cm}$ and average row to row distance is $45 \mathrm{~cm}$.

The depth of seed placement was $6 \mathrm{~cm}$ and actual seed rate observed was $13.2 \mathrm{~kg} / \mathrm{ha}$. The theoretical field capacity was $0.127 \mathrm{ha} / \mathrm{hr}$. The 
field efficiency calculated was $70.5 \%$. Average number of plants per hill was one. Cost of labour charges was Rs 500.00 per ha in sowing with three row inclined plate planter. The fatigue score of the bullocks was observed to be 15 after two hours of work, well within safe limit of 20 .

The mean draft measured during experiment was observed to be $351.83 \mathrm{~N}$. The average speed of operation behind the plough was $1.54 \mathrm{~km} / \mathrm{h}$. The average seed to seed distance was $27.5 \mathrm{~cm}$ and average row to row distance is $41 \mathrm{~cm}$.

The average depth of seed placement was 8 $\mathrm{cm}$ and actual seed rate observed was $22.5 \mathrm{~kg} /$ ha. The theoretical field capacity was found to be $0.075 \mathrm{ha} / \mathrm{hr}$. The field efficiency was calculated to be $59 \%$.

Average number of plants per hill was 1.34 Cost of labour charges was Rs 2140.00 per ha in sowing behind the plough. The fatigue score of the bullocks was observed to be 14 , well within safe limit of 20 .

The cost economics of sowing of maize with animal drawn planter and behind the plough was compared. It was found that cost of sowing with three row inclined plate planter was Rs $30.00 / \mathrm{h}$ and sowing behind the plough was Rs50.00/h (Table 6).

\section{References}

Adekanye, Timothy Adesoye and Akande, Avoyunafa Mary (2015) Development and Evaluation of a Manual Multi - crop Planter for Peasant Farmers Elixir Agriculture $86 \quad$ (2015) 3509535101

Devnani, R.S. (1991) Agricultural Machinery design and data hand book RNAM ESCAP.

Kathirvel K, Shivaji KP and Manian R. (2001) Development and evaluation of a till planter for cotton. Agricultural Mechanisation in Asia, Africa and Latin America, Japan 32: 23-27.

Olajide, O. G and Manuwa, S.I (2014). Design, Fabricationand Testing of a Low-cost Row Planter for Peasant Farmers. Proceedings of the International Soil Tillage Research Organization (ISTRO) Nigeria Symposium. Pp. 94-100.

Sharma, D.N., Bansal, N.K. And Jain, M.L. (1983) "Design, development and testing of a Bullock Drawn single row seed cum fertilizer drill" A.M.A. Vol. VII 14(2): 37-40.

Upadhyaya, R.C. and Madan, M.L. (1985) Draught performance of Haryana and crossbred bullocks in different regions. Indian Journal of Animal Sciences 55(1): 50-54.

\section{How to cite this article:}

Prerana Priyadarsini Jena and Suryakanta Khandai. 2017. Performance Evaluation of Bullock Drawn Three-Row Inclined Plate Planter. Int.J.Curr.Microbiol.App.Sci. 6(11): 1545-1553. doi: https://doi.org/10.20546/ijcmas.2017.611.184 